\title{
Fusarium head blight incidence and detection of Fusarium toxins in wheat in relation to agronomic factors
}

\author{
A. Wenda-Piesik • G. Lemańczyk • M. Twarużek • \\ A. Błajet-Kosicka $\cdot$ M. Kazek • J. Grajewski
}

Accepted: 27 February 2017 / Published online: 11 March 2017

(C) The Author(s) 2017. This article is published with open access at Springerlink.com

\begin{abstract}
We investigated incidences of Fusarium head blight (FHB) and concentrations of six mycotoxins (deoxynivalenol, nivalenol, 3-acetyldeoxynivalenol, T2 toxin, HT-2 toxin and zearalenone) in wheat from 2010 to 2013. Field trials were conducted at the Experimental Station of Cultivar Testing in Chrzastowo, Poland $\left(53^{\circ} 11^{\prime} \mathrm{N}, 17^{\circ} 35^{\prime} \mathrm{E}\right)$. We examined the effects of four agronomic factors, including pre-crop type (corn, sugar beets and wheat), date of sowing (late autumn: November 8-December 9 or spring: March 29April 19), fungicidal application (untreated or treated with two applications) and cultivar (Monsun, Cytra), on FHB index (FHBi) and mycotoxin levels in order to minimize the risk of wheat grain contamination by mycotoxins via integrated pest management methods. The dominant Fusarium species observed on wheat heads were $F$. culmorum, F. avenaceum (Gibberella avenacea) and $F$. graminearum (Gibberella zeae), at
\end{abstract}

\footnotetext{
A. Wenda-Piesik $(\bowtie) \cdot$ M. Kazek

Department of Plant Growth Principles and Experimental Methodology, UTP University of Science and Technology, 20 Kordeckiego, 85-225 Bydgoszcz, Poland

e-mail: apiesik@utp.edu.pl

G. Lemańczyk

Department of Entomology and Molecular Phytopathology, UTP University of Science and Technology, 20 Kordeckiego,

85-225 Bydgoszcz, Poland
}

M. Twarużek · A. Błajet-Kosicka · J. Grajewski Faculty of Natural Sciences, Institute of Experimental Biology, Department of Physiology and Toxicology, Kazimierz Wielki University, 30 Chodkiewicza, 85-064 Bydgoszcz, Poland
$21.1 \%, 17.2 \%$ and $7.1 \%$, respectively. A monthly rainfall sum of $113.9 \mathrm{~mm}$ and a relatively low air temperature (monthly average $15.5^{\circ} \mathrm{C}$ ) resulted in the highest FHBi in untreated wheat (25.1\%). Agronomic factors crucial for the FHB incidence were the pre-crop, fungicidal treatments and cultivar selection. In wheat planted after wheat or corn, the FHBi was higher compared with a precrop of sugar beet. A double application of fungicides at $\mathrm{BBCH} 30-32$ with prothioconazole and spiroxamine and at a $\mathrm{BBCH} 65$ with fluoxastrobin and prothioconazole effectively reduced the FHBi and mycotoxin concentrations, respectively, in grain. The cultivar 'Cytra' had a greater FHBi (10.4\%) than 'Monsun' (4.6\%), and grain infestations by Fusarium species were also greater in 'Cytra', at $16.5 \%$, than in 'Monsun', at $11.2 \%$. Untreated cv. Cytra grown after corn in spring produced grains with the highest amounts of the mycotoxins, deoxynivalenol, 3-acetyldeoxynivalenol, zearalenone and HT-2 $(605,103,17.5$ and $5.53 \mu \mathrm{g} / \mathrm{kg}$, respectively). Total mycotoxin levels in wheat were correlated with five determinants: duration of the period between the end of flowering and the beginning of kernel abscission, FHBi, F. culmorum isolation, G. zeae isolation and Fusarium ratio (FR) as a \% of total mould isolations. Although, the mean concentration of mycotoxins in grain did not exceed the maximum permissible values for unprocessed wheat our study suggests necessity to monitor and mitigate FHB risk for susceptible cultivars, when wheat spring sowing follows corn or wheat.

Keywords Wheat - Agronomic factors · Fusarium head blight $\cdot$ Mycotoxins 


\section{Introduction}

Food security and quality are important issues for a rapidly growing human population. The European Union (EU) is one of the world's major cereal producers and consumers, with wheat being the most important cereal consumed. The five biggest EU wheat producers are currently France, Germany, the United Kingdom, Poland and Romania (EC 2015). Fungal pathogens produce an extraordinary diversity of biologically active secondary metabolites. Health risks associated with the consumption of cereal products contaminated with Fusarium mycotoxins are of major concern worldwide (Groves et al. 1999; Desjardins 2006). Such dangerous compounds should be minimized in wheat, a primary source of carbohydrates for both humans and domesticated animals. In the last decade, human population growth, land degradation and global climate change have placed pressure on food production systems, resulting in a greater demand for cereals (FAO 2013). As a result, the principles of integrated pest management (IPM) have been incorporated into the European Union's (EU) Framework Directive on the sustainable use of pesticides and crop rotations (Council Directives 79/117/EEC and 91/414/EEC). IPM systems comprise many components, including soil tillage, crop rotation, resistance elicitors, cultivars and deployment of crops in mixtures (Park et al. 2009).

Species belonging to the genus Fusarium are ubiquitous in soil, air and water, and on plants and animals (Burgess 1981; Marasas et al. 1984; Nelson et al. 1994; Elvers et al. 1998; Bennett and Klich 2003; Nicholson et al. 2004). Depending on the ecological context, soilborne Fusarium species may be parasites, endophytes or pathogens of healthy host plants; they are known for their ability to survive in soil in the form of spores or as saprotrophs (Leslie et al. 2006; Aoki et al. 2014). The most common pathogens occurring on winter and spring wheat in Poland and Northern Europe are Fusarium culmorum (Wm.G. Sm) Sacc., Gibberella zeae (Schwein.) Petch (anamorph of Fusarium graminearum Schwabe), Gibberella avenacea R.J. Cook (anamorph of Fusarium avenaceum (Fr.) Sacc.), and Fusarium poae (Peck) Wollenw. Other Fusarium species (e.g. F. sporotrichioides (Sherb.)) are less important due to their reduced incidences and aggressiveness in the Kujavia-Pomerania region of the northern plains of Central Europe (Wakuliński and Chełkowski 1993;
Bai and Shaner 1994; Parry et al. 1995; Chełkowski 1998; Arseniuk et al. 1999; Bottalico and Perrone 2002; Edwards 2004; Logrieco and Visconti 2004; Abdullah and Atroshi 2016; Basler 2016; Tralamazza et al. 2016; Weber et al. 2016). These pathogens cause various diseases, such as root rot, foot rot, stem base rot, crown rot, Fusarium seedling blight (FSB) and Fusarium head blight (FHB-scab). FHB reduces wheat grain quantity and quality (Champeil et al. 2004a; Xu et al. 2005; Schmidt et al. 2016), and this disease has re-emerged in many cereal-growing regions worldwide (MacMullen et al. 1997; Jones and Mirocha 1999). Several fungal secondary metabolites, including deoxynivalenol (DON), nivalenol (NIV), zearalenone (ZEN), moniliformin (MON) and their derivatives may contaminate wheat grains as a result of FHB (Bottalico 1998; Chełkowski 1998; Snijders 2004; Schollenberger et al. 2005; Wiśniewska 2005; Tralamazza et al. 2016). In Poland, DON and a derivative, 3-acetyldeoxynivalenol (ADON), were identified in 1985 (Visconti et al. 1986), while ZEN was found in 1980 (Chełkowski et al. 1984) and has been recorded only in low amounts (Perkowski et al. 1990, 1991, 1997).

Thus far, breeders have not been able to produce a wheat cultivar fully resistant to FHB (Korbas and Horoszkiewicz-Janka 2007), although breeding for resistance is a necessary long-term strategy. Planting Fusarium-infected seed for cereal crops results in reduced plant density due to seedling blight (Timmermans et al. 2009). Burlakoti et al. (2010) showed that combining resistance to initial infection (type I) and resistance to spread within infected spikes (type II) remarkably enhanced resistance to FHB caused by G. zeae (F. graminearum) in spring wheat. Thus, varieties should be chosen for planting based on a combination of data, including level and type of FHB resistance and tolerance to seedling blight.

Many reports state that the most effective method to reduce losses caused by FHB of wheat is to plant resistant crop varieties in combination with appropriate agronomical practices and chemical protections (Clark et al. 2009; Blandino et al. 2012; Willyerd et al. 2012). 25 spring wheat cultivars from the Polish National List and 35 resistant cultivars/ lines from Canada, Germany, Japan, Mexico and China were investigated by Góral and WalentynGóral (2014)) in 2010-2012 for their resistance to FHB following inoculation with $F$. culmorum. In Polish cultivars, the FHBI index (FHBi) was 
$28.1 \%$ (range of $15.8-45.6 \%$ ), while cultivars and lines from the resistant collection were mostly highly resistant to FHB (mean index was $5.5 \%$, at a range 0-26.0\%). Lines 'CJ 9306' and 'CJ 9311' and cultivar Sumai 3 (all from China) were very highly resistant and showed no disease symptoms (Góral and Walentyn-Góral 2014).

FHB incidence has been described in the context of various factors, such as the type of farming system (Champeil et al. 2004b; Lenc 2015a), agronomic practices (Czaban et al. 2011; Horoszkiewicz-Janka et al. 2012) and environmental conditions (Doohan et al. 2003). Agronomic practices, such as crop rotation, mineral fertilization, organic matter soil inputs, tilling and others, play crucial roles in the management of Fusarium diseases (Wegulo et al. 2015). Noninversion tillage may increase wheat grain infection by G. zeae as compared with inversion tillage, whereby residues are buried in the soil (Leplat et al. 2013). FHB's occurrence is strongly dependent on specific weather conditions, predominantly rainfall. Some studies suggest that tillage protects wheat against Fusarium infestation (Dill-Macky and Jones 2000), while others state that weather conditions are much more important (Schaafsma et al. 2001). According to Duveiller (2008) and the International Maize and Wheat Improvement Center (CIMMYT), two causative agents of FHB, G. zeae and F. culmorum, are strongly influenced by climatic changes. FHB outbreaks may result from an early rainy season combined with farming system changes, especially expansion of corn crop growing area and the presence of corn stubble residues (Zhang et al. 2012; Steinmüller et al. 2004). Airborne Fusariums are known to be transported long distances (Keller et al. 2014) and $G$. zeae aerobiological characteristics have been thoroughly investigated (Goswami and Kistler 2004). Still, the relationships between FHB and grain contamination by Fusarium mycotoxins with respect to agronomic factors need to be fully understood because wheat cultivation has been simplified, with wheat monocultures becoming more popular, especially in their winter forms.

The purpose of this work was to investigate the impact of four experimental factors, including crop sequence, sowing date, fungicide use and cultivar, on FHB of wheat to identify conditions that minimize the risk of grain contamination by mycotoxins via integrated pest management methods.

\section{Materials and methods}

Field trials

Three field experiments were conducted from 2010 to 2013 at the Experimental Station of Cultivar Testing in Chrzastowo ( $\left.53^{\circ} 11^{\prime} \mathrm{N} 17^{\circ} 35^{\prime} \mathrm{E}\right)$, Poland, KujaviaPomerania region, Naklo vicinity, using two wheat (Triticum aestivum L. emend. Fiori et Paol.) cultivars the bread group cv. Cytra and the qualitative group cv. Monsun. Neither cultivar requires vernalization and both can be sown in late fall (facultative term) or spring. Crops were planted in the Alfisols typical of the region, which were classified as "wheat good complex" according to the Polish Soil Classification. A cultivator with a roller was used for ploughing and tilling of 72 total plots $\left(16.5 \mathrm{~m}^{2}\right)$. Seeds were placed at $3 \mathrm{~cm}$ depth with $12 \mathrm{~cm}$ row spacing; the target density (TD) of wheat was 500 seedlings $\mathrm{m}^{-2}$. According to the standard practices recommended by the Centre for Cultivar Testing (COBORU 2013), nitrogen fertilizer was applied with the following schedule: $40 \mathrm{~kg}$ of $\mathrm{N}$ per hectare before sowing, $50 \mathrm{~kg}$ per hectare at the 31-32 stage of the $\mathrm{BBCH}$ scale (Biologische Bundesanstalt, Bundessortenamt und Chemische Industrie) (Witzenberger et al. 1989; Lancashire et al. 1991) and $40 \mathrm{~kg}$ per hectare at the $\mathrm{BBCH} 45-47$ stage. Phosphorus and potassium were applied in doses of $60 \mathrm{~kg} \mathrm{P}_{2} \mathrm{O}_{5}$ and $75 \mathrm{~kg} \mathrm{~K} \mathrm{~K}_{2} \mathrm{O}$ per hectare, respectively, before sowing. Seeds were coated with Baytan Universal 094 FS (triadimenol $75 \mathrm{~g} / \mathrm{L}$, imazalil $10 \mathrm{~g} / \mathrm{L}$, fuberidazol $9 \mathrm{~g} /$ L) at $400 \mathrm{~mL}$ per $100 \mathrm{~kg}$ seeds. The dates of wheat sowing, fungicide applications and disease assessments during the three study years are presented in Table 1.

\section{Factors and treatments}

Experimental factors and treatments included pre-crop type (sugar beet, corn, wheat), sowing date (late autumn, spring), cultivar type (Cytra, Monsun) and fungicide application. These cultivars exhibit differential susceptibilities to Fusarium. The popular 'Monsun' cultivar, which produces a greater seed yield than 'Cytra', displays unstable, moderate FHB susceptibility, while 'Cytra' is stably susceptibility to FHB (Góral and Walentyn-Góral 2014). Fungicide applications included a control group designated "untreated" (without foliar and head treatments), and a treatment program designated "fungicide", based on two treatments, 
Table 1 The dates of wheat sowing, anthesis, fungicide applications and disease assessments during the three study years

\begin{tabular}{|c|c|c|c|c|c|c|}
\hline & \multicolumn{6}{|l|}{ Year } \\
\hline & \multicolumn{2}{|l|}{$2010-2011$} & \multicolumn{2}{|l|}{ 2011-2012 } & \multicolumn{2}{|l|}{ 2012-2013 } \\
\hline & Late autumn & Spring & Late autumn & Spring & Late autumn & Spring \\
\hline Date of wheat sowing & 09.12 .2010 & 01.04 .2011 & 08.11 .2011 & 29.03 .2012 & 16.11.2012 & 19.04.2013 \\
\hline \multicolumn{7}{|l|}{ Date of BBCH 65} \\
\hline Sugar beet pre-crop & $07^{\mathrm{M}} / 10.06^{\mathrm{C}}$ & $10 / 14.06$ & $09 / 12.06$ & $17 / 23.06$ & $15 / 17.06$ & $21 / 24.06$ \\
\hline Corn pre-crop & 06/09.06 & $09 / 13.06$ & $10 / 13.06$ & $18 / 23.06$ & $22 / 28.06$ & $22 / 26.06$ \\
\hline Wheat pre-crop & $06 / 09.06$ & $09 / 13.06$ & $09 / 12.06$ & $16 / 20.06$ & $14 / 17.06$ & $21 / 24.06$ \\
\hline \multicolumn{7}{|l|}{ Date of treatments } \\
\hline \multirow[t]{2}{*}{ Sugar beet pre-crop } & $05^{\mathrm{M}} / 09^{\mathrm{C}} .05^{\mathrm{T} 1}$ & 26/29.05 & $07 / 16.05$ & $27.05 / 01.06$ & 16/21.05 & 01/05.06 \\
\hline & $14 / 18.06 .^{\mathrm{T} 2}$ & 20/24.06 & 14/17.06. & 17/21.06 & 17/21.06. & $24 / 26.06$ \\
\hline \multirow[t]{2}{*}{ Corn pre-crop } & 09/13.05 & 30.05./04.06 & 16./21.05. & 01/06.06. & $21 / 26.05$ & 05/10.06 \\
\hline & $20 / 24.06$ & $24 / 28.06$ & $17 . / 21.06$ & $21 / 26.06$ & $24 / 29.06$ & $24 / 26.06$ \\
\hline \multirow[t]{2}{*}{ Wheat pre-crop } & 05/09.05. & 26/29.05 & $07 / 16.05$ & 27.05./01.06. & 16/21.05. & 01/05.06. \\
\hline & $14 / 18.06$ & 20/24.06. & 14/17.06 & 17/21.06. & 17/21.06 & $21 / 24.06$ \\
\hline \multicolumn{7}{|l|}{ Date of assessment } \\
\hline FHB & 12.07 & 18.07. & 11.07. & 17.07. & 12.07. & 22.07. \\
\hline
\end{tabular}

made at $\mathrm{T} 1(\mathrm{BBCH} 30-32)$ and $\mathrm{T} 2(\mathrm{BBCH} 65)$, with the first treatment a mixture of prothioconazole and spiroxamine (commercial product Input $460 \mathrm{EC}$ at dose $1 \mathrm{~L} / \mathrm{ha}$ ) and the second a mixture of fluoxastrobin and prothioconazole (Fandango 200 $\mathrm{EC}$ at dose $1 \mathrm{~L} / \mathrm{ha}$ ). A total of 24 combinations of 4 experimental factors in 3 replications in the splitplot-block layout were studied.

\section{Disease assay}

Wheat heads at $\mathrm{BBCH} 77$ (late milk stage) were selected from 100 random plants on each wheat plot, and per cent index of Fusarium head blight (FHBi) was assessed according to the procedures established in OEPP/EPPO PP 1/26(4) (2012)). The number of husks showing FHB symptoms per head and the number of diseased heads were used to calculate $\mathrm{FHBi}$, designating the percentage of all heads with disease symptoms. Tissue samples were collected and examined using a Leica DM 2500 microscope and Leica M125 stereomicroscope. Fungal isolation in artificial media was required for the identification of pathogenic species.
Identification techniques

One hundred $5 \mathrm{~mm}^{2}$ fragments were cut out from the borders of both healthy and infected ear husks. Prepared material was rinsed for $45 \mathrm{~min}$ in running water, disinfected in $1 \% \mathrm{AgNO}_{3}$ solution for $15 \mathrm{~s}$, rinsed three times for one min each time in sterile distilled water and placed on Potato Dextrose Agar (PDA; Difco) with streptomycin $(50 \mathrm{mg} / \mathrm{L})$ in Petri plates. Fungi were incubated for $7-10$ days at $20{ }^{\circ} \mathrm{C}$ in a day-night cycle. The colonies on each plate were then examined macroand microscopically and distinguished on the basis of colour, hyphal characteristics, growth rates, and sporulation rates. Colonies of each species were counted and representative fungi were identified by morphotyping on PDA and Synthetic Nutrient Agar (SNA; $\mathrm{KH}_{2} \mathrm{PO}_{4}$ $1 \mathrm{~g} / \mathrm{L}, \mathrm{KNO}_{3} 1 \mathrm{~g} / \mathrm{L}, \mathrm{MgSO}_{4} \cdot 7 \mathrm{H}_{2} \mathrm{O} 0.5 \mathrm{~g} / \mathrm{L}, \mathrm{KCl} 0.5 \mathrm{~g} / \mathrm{L}$, glucose $0.2 \mathrm{~g} / \mathrm{L}$, and sucrose $0.2 \mathrm{~g} / \mathrm{L}$ ) using the protocols of Booth (1971) and Kwaśna et al. (1991).

To confirm the species classification of Fusarium isolates, additionally polymerase chain reactions (PCR) were performed. The PCR assay was performed on selected isolates that, using traditional methods, were determined as $G$. avenacea ( $F$. avenaceum), F. culmorum and G. zeae. Every year we examined 20 
isolates from each species. Species-specific SCAR (Sequence Characterized Amplified Region) primers, JIAF/R for G. avenacea (Turner et al. 1998), $\mathrm{Fc} 01 \mathrm{~F} / \mathrm{R}$ for F. culmorum and Fg16NF/Fg16NR for G. zeae (Nicholson et al. 1998), were used. DNA was extracted according to the modified Doyle and Doyle (1990) method. The amplification reactions were carried out in a thermocycler (Eppendorf Mastercycler ep gradient, Germany) using a Taq PCR Core Kit (QIAGEN Inc., USA). The PCR products were separated in TBE buffer by electrophoresis in $1.4 \%$ agarose gels stained with ethidium bromide and visualized under UV light.

\section{Mycological analysis}

Harvested material from the experimental plots (grain at $14 \%$ moisture with a minimum weight of $500 \mathrm{~g}$ ) was thoroughly mixed and milled under sterile conditions. Twenty g of each sample was placed individually in a sterile bag of a Stomacher-type homogenizer, suspended in $180 \mathrm{~mL}$ of sterile liquid prepared according to PN EN ISO 6887-1 and homogenized for $90 \mathrm{~s}$. Determination of the total number of fungal species was carried out according to PN ISO 7954 with one alteration (spread plate method of $1 \mathrm{~mL}$ and $0.1 \mathrm{~mL}$, in triplicate). From the initial homogenized mixture (material diluted 1:10) a series of dilutions were performed. The inoculation was performed according to Koch on Yeast Extract Glucose Chloramphenicol Agar (YGC). Samples were incubated for 5-7 days at $25 \pm 1{ }^{\circ} \mathrm{C}$. Following incubation, colonies were counted and the results were expressed as the number of colony forming units (CFU) per $1 \mathrm{~g}$ of sample [cfu/g].

Mycotoxin analysis

$12.5 \mathrm{~g}$ of harvested grain was homogenized with $50 \mathrm{~mL}$ of $\mathrm{ACN}: \mathrm{H}_{2} \mathrm{O}$ (80:20) for $3 \mathrm{~min}$ and the extract was filtered using Fluted Filter Paper (Vicam). $40 \mu \mathrm{l}$ of zearalanone (ZAN, internal standard for ZEN) solution was added to $4 \mathrm{ml}$ of the extract, and the mixture was applied to a BondElut Mycotoxin ${ }^{\circledR}$ column (Agilent). Then, $50 \mu \mathrm{l}$ of internal standard solutions $\left({ }^{13} \mathrm{C}\right.$ DON, ${ }^{13} \mathrm{C}$ T-2 toxin, ${ }^{13} \mathrm{C}$ HT-2 toxin) were added to $2 \mathrm{ml}$ of the purified extract, and the mixture was evaporated to dryness under nitrogen. Then, $495 \mu \mathrm{l}$ of $\mathrm{MeOH}: \mathrm{H}_{2} \mathrm{O}$ 1:4 was added to the vial and the sample was vortexed. The analytical method of liquid chromatography tandem mass spectrometry (LCMS/MS) used mycotoxin standards for the analysis of the major metabolites of Fusarium. Mycotoxin presence and concentration (deoxynivalenol $=\mathrm{DON}$, nivalenol $=$ NIV, $3-$ Acetyldeoxynivalenol $=$ ADON, T-2 toxin $=$ T2, HT-2 toxin = HT-2 and zearalenone $=$ ZEN) was assessed using HPLC with MS/MS detection. HPLC: Nexera (Shimadzu, USA); mass spectrometer: API 4000 (AB Sciex, Foster City, CA, USA); chromatographic column: Gemini C18 (150 × $4.6 \mathrm{~mm}, 5 \mu \mathrm{m})$ (Phenomenex Inc., Torrance, CA, USA); mobile phase: A: $\mathrm{H}_{2} \mathrm{O}+5 \mathrm{mM} \mathrm{CH}_{3} \mathrm{COONH}_{4}+1 \% \mathrm{CH}_{3} \mathrm{COOH}$, B: $\mathrm{MeOH}+5 \mathrm{mM} \mathrm{CH}_{3} \mathrm{COONH}_{4}+1 \% \mathrm{CH}_{3} \mathrm{COOH}$; flow rate: $0.7 \mathrm{ml} / \mathrm{min}$; injection volume: $10 \mu \mathrm{l}$. Limits of detection (LODs) and limits of quantification (LOQs) were 1 and $3 \mu \mathrm{g} / \mathrm{kg}$, respectively, for DON, NIV and ADON; 0.2 and $0.6 \mu \mathrm{g} / \mathrm{kg}$ for $\mathrm{T}-2,0.7$ and $2 \mu \mathrm{g} /$ $\mathrm{kg}$ for HT-2 and 0.06 and $0.2 \mu \mathrm{g} / \mathrm{kg}$ for ZEN. For statistical analyses, samples below LOQ were given at the LOQ value.

Statistical analyses

The arcsine angular transformation according to the Bliss (1938)) was used to obtain a normal distribution for FHBi (\%) and Fusarium ratio (\%). The Bliss transformation is typically applied to data having original binomial distributions expressed in percentage, most frequently assuming values within the range of 0 $100 \%$. Mould $(\mathrm{cfu} / \mathrm{g}), \mathrm{DON}(\mu \mathrm{g} / \mathrm{kg})$ and ZEN $(\mu \mathrm{g} / \mathrm{kg})$ concentrations in grain were $\log$-transformed due to high right skewing. The other mycotoxins were not statistically analysed due to levels of low detection or lack of repeatability within and between years and treatments. Shapiro-Wilk's test was used to assess normality. The variables, FHBi, overall moulds concentration, Fusarium ratio, DON and ZEN concentration, were analysed by five-way mixed model (years was a random effect); pre-crop type, sowing date, fungicide application and wheat cultivar were the fixed effects. Analyses of variance (ANOVA) were carried out to determine the effects of year and all fixed factors, as well as the 2nd order interactions between fixed factors, estimated by the GLM for split-plot-block design with 4 residuals. The higher order (3rd, 4th) interactions between effects and the interactions of random (years) with fixed factors were omitted to avoid the confounding of main effects and the low-order interactions with higher order interactions (Hinkelmann and Kempthorne 2005). The means were separated according to Tukey's HSD test 
with $p \leq 0.05$ designating a significant difference. Mean data from the two cultivars $\mathrm{x}$ three pre-crop types $\mathrm{x}$ fungal treatment type $\mathrm{x}$ three years $(n=36)$ were used to assess correlations between total mycotoxin concentration and 5 determinant variables: development duration at $\mathrm{BBCH} 71-89$, FHBi, G. zeae and F. culmorum ratio and total Fusarium ratio (FR) in wheat grain separately for two dates of sowing, according to the $r$ Pearsons' coefficient. These variables were chosen following the ANOVA and means separations, as we noticed that in spring sowings the mean values were higher and the ranges were wider than in the late autumn sowings (Table 6). We therefore calculated correlations separately for the 36 cases of late autumn sowing and 36 cases of spring sowing. For this value of n, $p=0.05$ corresponds to $r=0.33$, and $p=0.01$ corresponds to $r=0.42$. Analyses were performed using Statistica 12.0, StatSoft software.

\section{Results}

Head and grain infestation

The Monsun cultivar grew and developed faster than cv. Cytra, and late-autumn-sown crops grew and developed faster than spring-sown crops (Table 1). In 2011 plants reached $\mathrm{BBCH} 65$ (50\% of anthers mature) between June 7-16, when rainfall was low (decade sum 6.9$15.6 \mathrm{~mm}$ ) and air temperature was high (average $20{ }^{\circ} \mathrm{C}$ ) (Table 2). Average FHBi was $6.96 \%$ overall, and was highest for wheat sown in spring (11.5\%, Table 3). In 2012, half anthesis occurred in the 2nd and 3rd week of June (Table 1), with abundant rain (monthly sum $113.9 \mathrm{~mm}$ ) and relatively low air temperature (monthly average $15.5^{\circ} \mathrm{C}$ ). The highest FHBi was noted in untreated wheat $(25.1 \%)$ and was significantly higher in wheat sown after a pre-crop of wheat or corn as compared to sugar beet (Table 4). The cold spring in the third year caused slower crop growth, and wheat plants reached BBCH 65 just after mid-June, with little precipitation (decade sum $0.5 \mathrm{~mm}$ ) and moderate temperature $18.6{ }^{\circ} \mathrm{C}$. This season did not favour the Fusarium infection, and FHBi was $4.64 \%$. Over all study years, three of the four agronomic factors had significant effects on FHBi. When wheat followed after wheat or corn (pre-crop, $F_{(2 ; 4)}=10.6$ ), FHBi was higher compared with a pre-crop of sugar beet. A double application of fungicides at $\mathrm{BBCH} 30-32$ and $\mathrm{BBCH} 65$ (fungicidal factor, $\left.F_{(1 ; 2)}=24.5\right)$ resulted in significantly reduced FHBi $(2.6 \%)$ compared with untreated wheat $(14.5 \%)$. The Cytra cultivar (cultivar effect, $F_{(1 ; 2)}=19.8$ ) had an FHBi twice that of cv. Monsun (Tables 3 and 4).

Results are means from 2011 to 2013. Fungicide treatments are untreated and a program based on two treatments at $\mathrm{T} 1(\mathrm{BBCH} 30-32)$ and $\mathrm{T} 2(\mathrm{BBCH} 65)$, where the first treatment is an application of a mixture of prothioconazole and spiroxamine and the second is a mixture of fluoxastrobin and prothioconazole.

The dominant Fusarium species, identified based on morphology, that occurred on wheat heads was F. culmorum (21.1\%), followed by $G$. avenacea (F. avenaceum) (17.2\%), while G. zeae (F. graminearum) isolations were sparse $(7.1 \%)$ over all treatments (Fig. 1). Other species were present in up to $54.5 \%$ of isolations, although most were identified as non-pathogenic. Wheat grown after corn revealed the highest prevalence of FHB species (over 60\%). However, the three Fusarium species were identified twice as frequently when wheat was grown in monoculture than after sugar beets (Fig. 1). Furthermore, in untreated wheat, $60 \%$ of the fungal samples isolated were recognized as FHB-causative species. Fusarium species composed $60 \%$ of isolated fungi for wheat sown in spring, and only $27 \%$ in autumn (Fig. 1). The identification of $G$. avenacea, $F$. culmorum and ( $G$. zeae) $F$. graminearum was additionally carried out using the PCR assay with species-specific SCAR primers. The $\mathrm{JIAF} / \mathrm{R}$ primers verified the previous microscopic identification of $G$. avenacea and confirmed that all of the selected isolates belonged to this species. For the $G$. avenacea isolates, the amplification product of $220 \mathrm{bp}$ was obtained. The identifications of $F$. culmorum and G. zeae were confirmed using the $\mathrm{Fc} 01 \mathrm{~F} / \mathrm{R}$ and $\mathrm{Fg} 16 \mathrm{NF} / \mathrm{Fg} 16 \mathrm{NR}$ primer sets, respectively. The F. culmorum isolates' product of $570 \mathrm{bp}$ was amplified, while for G. zeae the product was $280 \mathrm{bp}$.

The number of types of moulds found on wheat grains depended on three experimental factors: precrop $\left(F_{(2 ; 4)}=10.3\right)$, sowing date $\left(F_{(1 ; 2)}=27.4\right)$, and fungicide application $\left(F_{(1 ; 2)}=18.9\right)$, while the cultivar type was insignificant (Table 3, Fig. 2a-d). Measured moulds on grains (cfu/g) was similar for wheat grown after corn or after wheat, with the highest representation of Fusarium species in the case of wheat followed by wheat $(18.8 \%$,Fig. 3a). The spring date of sowing favoured the number of moulds on grain $(12,759 \mathrm{CFU} /$ g) and the ratio of Fusarium species (18.4\%). These 
Table 2 Rainfall (mm) and air temperature $\left({ }^{\circ} \mathrm{C}\right)$ in June-July in the years of study (2010-2013) and for the past five decades (1965-2014)

\begin{tabular}{|c|c|c|c|c|c|c|c|c|c|c|c|c|c|c|}
\hline \multirow[t]{3}{*}{ Month } & \multicolumn{4}{|c|}{ 2010-2011 } & \multicolumn{4}{|c|}{ 2011-2012 } & \multicolumn{4}{|c|}{ 2012-2013 } & \multicolumn{2}{|c|}{ 1965-2014 } \\
\hline & \multicolumn{2}{|l|}{$\mathrm{R}$} & \multicolumn{2}{|l|}{$\mathrm{T}$} & \multicolumn{2}{|l|}{$\mathrm{R}$} & \multicolumn{2}{|l|}{$\mathrm{T}$} & \multicolumn{2}{|l|}{$\mathrm{R}$} & \multicolumn{2}{|l|}{$\mathrm{T}$} & \multirow{2}{*}{$\begin{array}{l}\mathrm{R} \\
\mathrm{MS}\end{array}$} & \multirow{2}{*}{$\begin{array}{l}\mathrm{T} \\
\mathrm{MA}\end{array}$} \\
\hline & $\mathrm{DS}^{\#}$ & MS & $\mathrm{DA}^{*}$ & MA & DS & MS & DA & MA & DS & MS & DA & MA & & \\
\hline \multirow[t]{3}{*}{ June } & 6.9 & \multirow[t]{3}{*}{39.4} & 21.1 & \multirow[t]{3}{*}{19.5} & 4.9 & \multirow[t]{3}{*}{113.9} & 13.1 & \multirow[t]{3}{*}{15.5} & 19.0 & \multirow[t]{3}{*}{58.3} & 16.4 & 17.2 & \multirow[t]{3}{*}{63.9} & \multirow[t]{3}{*}{16.8} \\
\hline & 15.6 & & 18.3 & & 63.3 & & 16.6 & & 0.5 & & 18.6 & & & \\
\hline & 16.7 & & 19.2 & & 45.7 & & 16.9 & & 38.8 & & 16.7 & & & \\
\hline \multirow[t]{3}{*}{ July } & 32.6 & \multirow[t]{3}{*}{117.4} & 17.9 & \multirow[t]{3}{*}{18.5} & 40.3 & \multirow[t]{3}{*}{144.3} & 20.9 & \multirow[t]{3}{*}{19.5} & 31.2 & \multirow[t]{3}{*}{92.7} & 19.4 & \multirow[t]{3}{*}{20.8} & \multirow[t]{3}{*}{76.5} & \multirow[t]{3}{*}{18.3} \\
\hline & 60.3 & & 20.3 & & 38.4 & & 15.9 & & 20.1 & & 18.4 & & & \\
\hline & 24.5 & & 17.3 & & 65.6 & & 21.7 & & 41.4 & & 24.7 & & & \\
\hline
\end{tabular}

R: rainfall, T: temperature

\# DS: sum for a 10-day period, MS: monthly sum

*DA: average of a 10-day period, MA: monthly average

numbers were two- and three-folds higher for wheat planted in spring than in late autumn (Fig. 2b, 3b). A significant interaction was found between cultivar and sowing season $\left(F_{(1 ; 2)}=19.1\right)$, both for the number of moulds and Fusarium ratio (Fig. 2e, 3e). Cultivar Cytra was more susceptible (22.7\%) than Monsun (13.8\%) to grain infestation by Fusarium species (Fig. 3d) and was much more susceptible in spring $(22.7 \%)$ than in late autumn sowing $(9.00 \%)$ - Fig. 3e. A similar pattern was observed in the number of moulds found on both cultivars planted after the different pre-crop types (Fig. 2f, 3f). However, the ratio of Fusarium isolations to other moulds found on the two cultivars differed with respect to pre-crop type. Cytra planted after wheat was more susceptible to Fusarium (20.5\%) than Monsun (17.1\%). Moreover, the Fusarium ratio in the moulds from the

Table 3 Mean squares from analysis of variance with wheat characteristics

\begin{tabular}{|c|c|c|c|c|c|c|}
\hline & & FHBi & Moulds & Fusarium ratio & $\mathrm{DON}$ & ZEN \\
\hline Effect & $d f^{\#}$ & MS & MS & MS & MS & MS \\
\hline Year & 2 & $1.742 *$ & $3.562 *$ & $9.452 *$ & $1.856^{*}$ & $8.161^{*}$ \\
\hline Replication & 2 & 0.075 & 0.086 & 0.245 & 0.214 & 0.854 \\
\hline Pre-crop & 2 & $2.014 *$ & $4.261^{*}$ & 2.962 & $2.494 *$ & 3.262 \\
\hline Residual 1 & 4 & 0.190 & 0.412 & 1.575 & 0.332 & 0.857 \\
\hline Sowing date & 1 & 1.265 & $1.235^{*}$ & $9.399 *$ & $2.734 *$ & 3.440 \\
\hline Pre-crop $\mathrm{x}$ sowing date & 2 & 0.128 & 0.058 & 5.412 & $2.655^{*}$ & 2.655 \\
\hline Residual 2 & 2 & 0.110 & 0.045 & 0.481 & 0.135 & 0.564 \\
\hline Fungicide application & 1 & $5.145^{*}$ & $5.420 *$ & $13.26^{*}$ & $11.32 *$ & $5.537 *$ \\
\hline Sowing date $\mathrm{x}$ fungicide application & 1 & 0.874 & 1.369 & 4.235 & 3.523 & 1.256 \\
\hline Pre-crop x fungicide application & 2 & 0.972 & 1.955 & 6.874 & 4.654 & 2.415 \\
\hline Residual 3 & 2 & 0.210 & 0.285 & 0.663 & 0.452 & 0.275 \\
\hline Cultivar & 1 & $3.385^{*}$ & 1.243 & $3.883 *$ & $2.630 *$ & $4.312^{* *}$ \\
\hline Cultivar x pre-crop & 2 & 1.124 & 0.254 & $3.568 *$ & $2.642 *$ & $2.851^{*}$ \\
\hline Cultivar $\mathrm{x}$ sowing date & 1 & 0.654 & $1.351 * *$ & $4.251 *$ & $2.874 *$ & $2.564 *$ \\
\hline Cultivar $\mathrm{x}$ fungicide application & 1 & 0.454 & 0.012 & 1.245 & 1.555 & 0.954 \\
\hline Residual 4 & 2 & 0.171 & 0.071 & 0.185 & 0.142 & 0.103 \\
\hline
\end{tabular}

\#: $d f:$ degree of freedom, * significant at $p=0.05, * *$ significant at $p=0.01$ 
Table 4 Fusarium head blight index (FHBi) on wheat for different pre-crop types, sowing dates, fungicide treatments and cultivars. Data represent means $\pm \mathrm{s}_{\mathrm{e}}$

\begin{tabular}{|c|c|c|c|c|}
\hline \multirow[t]{2}{*}{ Treatment } & \multicolumn{4}{|l|}{ Growing season } \\
\hline & 2010/2011 & $2011 / 2012$ & $2012 / 2013$ & Overall \\
\hline \multicolumn{5}{|l|}{ Pre-crop } \\
\hline Wheat & $5.5 \pm 0.65 \mathrm{ab}^{\$}$ & $20.4 \pm 1.25 \mathrm{a}$ & $3.5 \pm 0.35 \mathrm{a}$ & $9.80 \pm 0.45 \mathrm{~A}$ \\
\hline Corn & $8.5 \pm 0.55 \mathrm{a}$ & $18.5 \pm 1.00 \mathrm{a}$ & $6.5 \pm 0.35 \mathrm{a}$ & $11.17 \pm 0.38 \mathrm{~A}$ \\
\hline Sugar beet & $3.5 \pm 0.45 b$ & $6.5 \pm 0.65 b$ & $3.5 \pm 0.35 \mathrm{a}$ & $4.50 \pm 0.29 \mathrm{~B}$ \\
\hline \multicolumn{5}{|c|}{ Date of sowing } \\
\hline Spring & $11.5 \pm 1.25 \mathrm{a}$ & $15.6 \pm 1.35 \mathrm{a}$ & $6.7 \pm 0.75 \mathrm{a}$ & $11.3 \pm 0.97 \mathrm{~A}$ \\
\hline Late autumn & $5.50 \pm 0.65 \mathrm{~b}$ & $13.8 \pm 1.55 \mathrm{a}$ & $3.2 \pm 0.69 \mathrm{~b}$ & $7.50 \pm 0.89 \mathrm{~A}$ \\
\hline \multicolumn{5}{|l|}{ Fungicides } \\
\hline Untreated & $10.5 \pm 1.30 \mathrm{a}$ & $25.1 \pm 1.25 \mathrm{a}$ & $7.90 \pm 0.65 \mathrm{a}$ & $14.5 \pm 0.86 \mathrm{~A}$ \\
\hline Fungicide & $2.40 \pm 0.25 \mathrm{~b}$ & $3.40 \pm 0.15 b$ & $2.00 \pm 0.34 \mathrm{~b}$ & $2.6 \pm 0.24 \mathrm{~B}$ \\
\hline \multicolumn{5}{|l|}{ Cultivar } \\
\hline Cytra & $10.4 \pm 0.95 \mathrm{a}$ & $15.8 \pm 0.80 \mathrm{a}$ & $5.00 \pm 0.51 \mathrm{a}$ & $10.4 \pm 0.64 \mathrm{~A}$ \\
\hline Monsun & $4.80 \pm 0.35 b$ & $5.50 \pm 0.43 b$ & $3.50 \pm 0.09 \mathrm{a}$ & $4.60 \pm 0.37 \mathrm{~B}$ \\
\hline Overall & $6.96 \pm 0.45$ & $13.84 \pm 0.48$ & $4.64 \pm 0.32$ & $8.48 \pm 0.55$ \\
\hline
\end{tabular}

$\$$ the same letters indicate the homogenous group according to HSD Tukey's test at $p=0.05$ small letters within the year of study for individual treatment, big letters for the individual treatment effects overall the years

grain was significantly higher in case of Cytra than in case of Monsun planted after corn or sugar beet (Fig. 3f). The number of mould units from untreated wheat grain was almost three times as high, and Fusarium isolations three times higher, as that from grain of fungicide-treated wheat (Fig. 2d, 3d). The fungicide program, including prothioconazole and spiroxamine at $\mathrm{T} 1$ and a mixture of fluoxastrobin and prothioconazole at $\mathrm{T} 2$, effectively reduced both total moulds on grain (cfu/g) and Fusarium isolations.
Fig. 1 Fusarium species isolations on wheat heads for different pre-crop types (wheat, corn, beet), sowing seasons (late autumn, spring, ), fungicide treatments and cultivars (Cytra, Monsun)

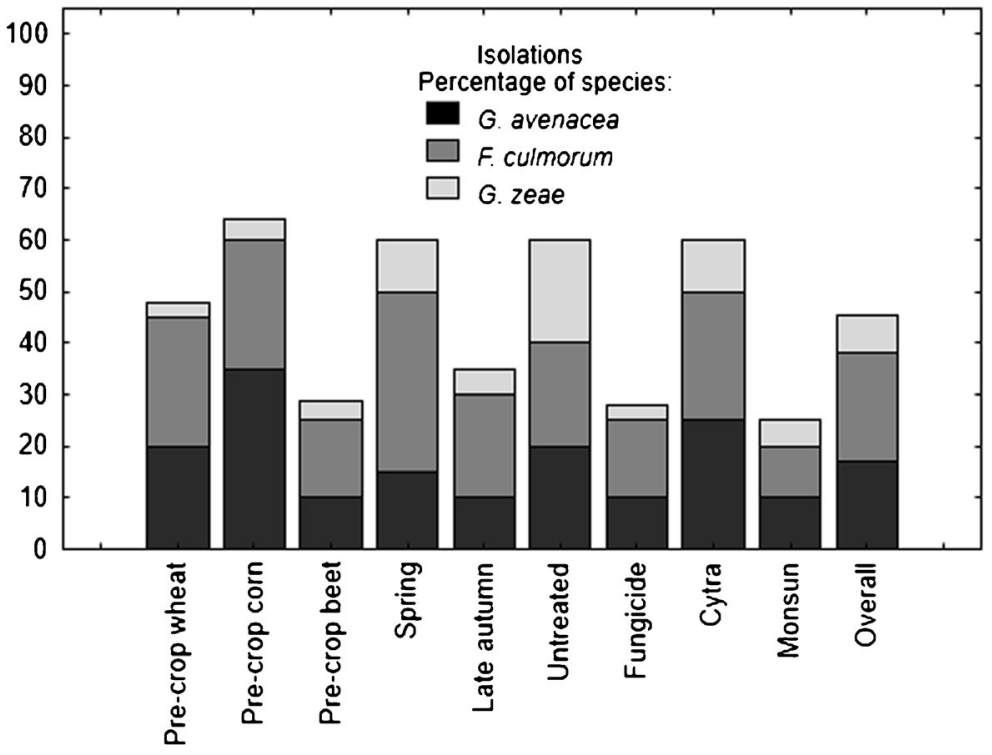



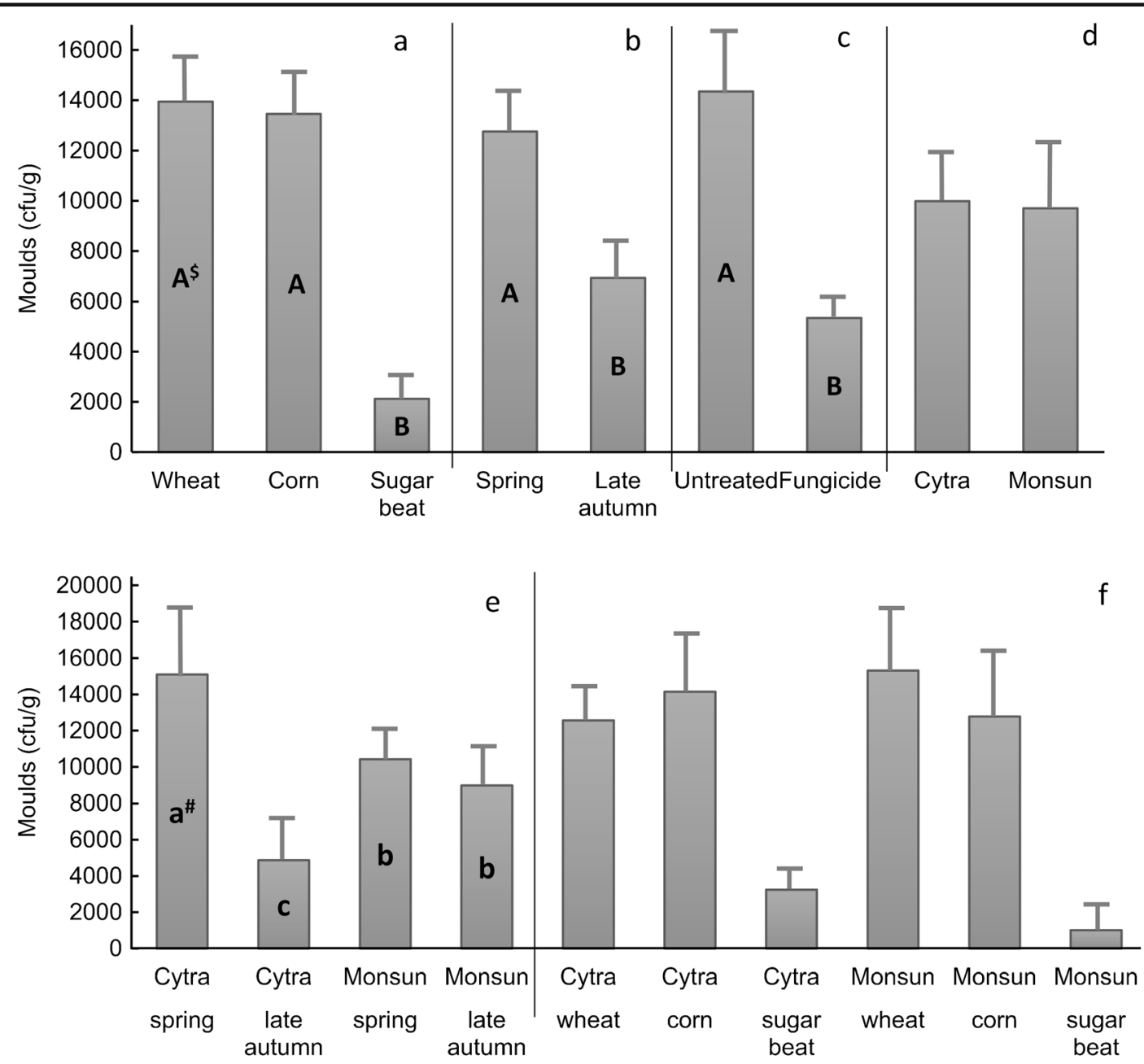

Fig. 2 The amount of mould (CFU/g) on wheat grains for different pre-crop types (a), sowing dates (b), fungicide treatments (c), cultivars (d) and interactions between cultivars / sowing date (e) and cultivars / pre-crop type (f). Data represent means $+\mathrm{s}_{\mathrm{e}}{ }^{\$}$ the same letters indicate the homogenous group according to HSD

Mycotoxin profile and quantities depend on pre-crop type, fungicide control, sowing date and wheat cultivar

The concentrations of six mycotoxins were recorded: DON, NIV, ADON, ZEN, HT-2 and T-2. Data for DON and ZEN were analysed by ANOVA as only these mycotoxins were present in more than $80 \%$ of samples (excluding samples below LOQ). In 2012, the highest DON concentration $(1250 \mu \mathrm{g} / \mathrm{kg}$ ) was recorded (data not shown) for the grain of cv. Cytra sown in the spring after corn, without fungicidal control. DON concentration was affected by the main agronomic factors and their interactions: pre-crop of wheat $\left(F_{(2 ; 4)}=7.51\right)$, sowing season $\left(F_{(1 ; 2)}=20.3\right)$, interaction between pre-crop
Tukey's test at $p=0.05$ for the individual treatment effects overall the years, \# small letters indicate the homogenous group according to HSD Tukey's test at $p=0.05$ for within the interactions overall the years

and wheat sowing season $\left(F_{(1 ; 2)}=19.7\right)$, fungicidal treatment $\left(F_{(1 ; 2)}=25.0\right)$, cultivar $\left(F_{(1 ; 2)}=18.5\right)$, the cultivar and pre-crop interaction $\left(F_{(1 ; 2)}=18.6\right)$, and the cultivar and sowing season interaction $\left(F_{(1 ; 2)}=20.2\right)$ (Table 3). ZEN concentration was affected by fungicidal treatment $\left(F_{(1 ; 2)}=20.1\right)$, cultivar $\left(F_{(1 ; 2)}=41.9\right)$, the cultivar and pre-crop interaction $\left(F_{(1 ; 2)}=27.7\right)$, and the cultivar and sowing date interaction $\left(F_{(1 ; 2)}=24.9\right)$ (Table 3). The mean values for all mycotoxins from all study years, except the mean for T-2 toxin, which was below LOQ, are presented in Table 5. Generally, mycotoxin concentrations were higher for $\mathrm{cv}$. Cytra than $\mathrm{cv}$. Monsun, and were favoured by spring season sowing and pre-crop of wheat or corn. Grain from untreated 

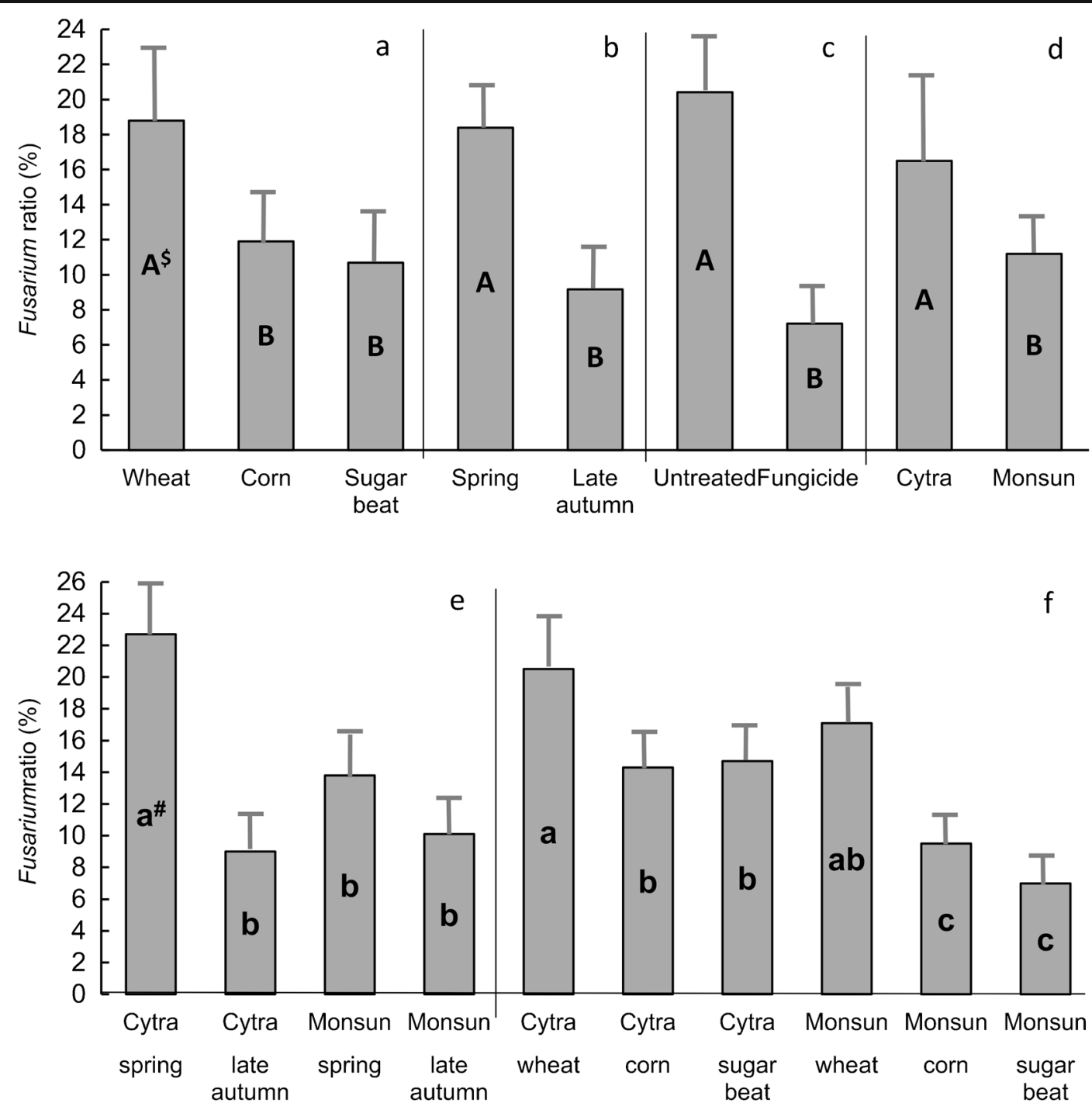

Fig. 3 The proportion of Fusarium on wheat grains for different pre-crop types (a), sowing dates (b), fungicide treatments (c), cultivars (d) and interactions between cultivars / sowing date (e) and cultivars / pre-crop type (f). Data represent means $+\mathrm{s}_{\mathrm{e}}$. Explanations $-\mathrm{see}$ Fig. 2

Cytra grown after corn in the spring had the highest concentrations of DON $(605 \mu \mathrm{g} / \mathrm{kg})$, ADON $(103 \mu \mathrm{g} /$ $\mathrm{kg}), \mathrm{ZEN}(17.5 \mu \mathrm{g} / \mathrm{kg})$ and HT-2 $(5.53 \mu \mathrm{g} / \mathrm{kg})$. Monsun under the same conditions produced grain with much lower toxin concentrations: DON, $154 \mu \mathrm{g} / \mathrm{kg}$; ADON, $11.6 \mu \mathrm{g} / \mathrm{kg} ; \mathrm{ZEN}, 1.07 \mu \mathrm{g} / \mathrm{kg}$; and HT-2 < $2 \mu \mathrm{g} / \mathrm{kg}$. Fungicidal treatment did not suppressed DON in Cytra grain when this wheat was grown after corn. Reduced toxin concentrations were observed in grain harvested from crops sown in late autumn as compared to spring crops (Table 5).

The relationships between mycotoxin concentration in wheat grain and five determinant variables were calculated using $r$-Pearson coefficient of correlation (Fig. 4). These determinants included: duration of the period between the end of flowering (BBCH 69) and the beginning of kernel abscission (fully ripe stage, $\mathrm{BBCH}$ 89), FHBi, F. culmorum isolations, G. zeae isolations and Fusarium ratio (FR) as a $\%$ of total isolations. Table 6 display the results of the mean and ranges of six characteristics where the tendency to the higher means and wider ranges refer to the spring sowings. We therefore calculated correlations separately for the 36 cases of late autumn sowing and 36 cases of spring sowing. Stronger positive correlations $(p<0.01)$ between six mycotoxin concentration and the agronomic 
Table 5 Toxic fungal metabolites in grains for different cultivars, dates of sowing, pre-crop types and fungicide treatments. Results are means from 2011 to 2013

\begin{tabular}{|c|c|c|c|c|c|c|c|c|c|c|c|c|}
\hline \multirow[t]{3}{*}{ Pre-crop type } & \multirow[t]{3}{*}{ Fungicide treatment ${ }^{1}$} & \multirow[t]{3}{*}{ Cultivar } & \multicolumn{10}{|c|}{ Toxic metabolites $(\mu \mathrm{g} / \mathrm{kg})$} \\
\hline & & & \multicolumn{2}{|l|}{ DON } & \multicolumn{2}{|l|}{ NIW } & \multicolumn{2}{|l|}{ ADON } & \multicolumn{2}{|l|}{ HT-2 } & \multicolumn{2}{|l|}{ ZEN } \\
\hline & & & $\mathrm{S}^{2}$ & $\mathrm{LA}^{3}$ & $\mathrm{~S}$ & LA & $\mathrm{S}$ & LA & $\mathrm{S}$ & LA & $\mathrm{S}$ & LA \\
\hline \multirow[t]{4}{*}{ Wheat } & \multirow[t]{2}{*}{ Untreated } & Monsun & 53.30 & 37.90 & $<3.00$ & $<3.00$ & 10.80 & $\mathrm{nd}^{4}$ & $<2.00$ & $<2.00$ & 1.76 & 0.30 \\
\hline & & Cytra & 181.40 & 91.70 & 6.05 & 6.92 & 42.40 & $<3.00$ & 5.10 & 3.83 & 7.89 & 0.86 \\
\hline & \multirow[t]{2}{*}{ Fungicide } & Monsun & 62.60 & 36.30 & 3.86 & $\mathrm{nd}^{4}$ & 7.27 & nd & $<2.00$ & nd & 5.67 & 0.23 \\
\hline & & Cytra & 146.50 & 66.10 & 9.52 & 3.33 & 22.46 & $<3.00$ & 8.06 & 2.40 & 3.26 & $<0.20$ \\
\hline \multirow[t]{4}{*}{ Corn } & \multirow[t]{2}{*}{ Untreated } & Monsun & 154.20 & 131.80 & 3.29 & $<3.00$ & 11.60 & $<3.00$ & $<2.00$ & $<2.00$ & 1.07 & 1.61 \\
\hline & & Cytra & 604.50 & 382.00 & 8.06 & 51.0 & 103.00 & 6.53 & 5.53 & 13.7 & 17.46 & 12.7 \\
\hline & \multirow[t]{2}{*}{ Fungicide } & Monsun & 67.40 & 120.00 & $<3.00$ & 4.86 & 21.10 & $<3.00$ & $<2.00$ & $<2.00$ & 0.53 & $<0.20$ \\
\hline & & Cytra & 441.50 & 221.30 & 13.0 & 13.6 & 85.50 & 3.44 & 2.12 & 6.63 & 5.66 & 6.22 \\
\hline \multirow[t]{4}{*}{ Sugar beet } & \multirow[t]{2}{*}{ Untreated } & Monsun & 64.10 & 116.70 & 5.58 & 4.90 & 14.70 & 17.30 & 3.13 & 4.26 & 0.71 & 0.52 \\
\hline & & Cytra & 181.80 & 204.60 & 7.58 & 12.70 & 20.63 & 29.78 & 13.50 & 2.9 & 3.73 & 3.44 \\
\hline & \multirow[t]{2}{*}{ Fungicide } & Monsun & 24.50 & 52.90 & 4.66 & 4.14 & 6.08 & 15.30 & $<2.00$ & 2.51 & 0.76 & 1.53 \\
\hline & & Cytra & 232.40 & 128.50 & 7.02 & $<3.00$ & 43.80 & 5.30 & 11.50 & nd & 3.01 & 3.58 \\
\hline
\end{tabular}

DON deoxynivalenol, NIV nivalenol, ADON 3-acetyldeoxynivalenol, HT-2 toxin, ZEN zearalenone

Fungicide: program based on two treatments at $\mathrm{T} 1$ (BBCH 30-32) and $\mathrm{T} 2$ (BBCH 65), where the first treatment is an application of a mixture of prothioconazole and spiroxamine and the second is a mixture of fluoxastrobin and prothioconazole

${ }^{2} \mathrm{~S}$ : spring sowing

${ }^{3}$ LA: late autumn sowing

${ }^{4}$ nd : not detected

determinants were obtained for spring-sown wheat. Longer development times between $\mathrm{BBCH} 69$ and 89 correlated with higher mycotoxin levels $(r=0.85)$, as shown by increasing FR $(r=0.86)$ and increasing incidences of both $G$. zeae $(r=0.70)$ and F. culmorum $(r=0.65)$ on wheat heads (Fig. 4). For late autumn wheat, mycotoxin levels correlated only with FHBi $(r=0.51), G$. zeae $(r=0.67)$ and F. culmorum isolations $(r=0.88)$, and not with BBCH 69-89 duration and FR in grain. G. zeae isolations correlated with mycotoxin concentrations in grain at the same level in both sowing seasons (Fig. 4).

\section{Discussion and conclusions}

In the present study, four agronomic fixed factors (precrop, sowing date, fungicide treatment and cultivar) were studied in relation to FHBi, FR, Fusarium species present on grain and the concentrations of six FHBassociated mycotoxins in planted wheat crops. F. culmorum was the dominant species occurring on wheat heads $(21.1 \%)$. This pathogen is one of the predominant Fusarium spp. in cooler climates such as northern, central and western Europe (Wagacha and Muthomi 2007), as well as in Poland (Golinski et al. 2002; Korbas and Horoszkiewicz-Janka 2007; Lenc 2015a; Weber et al. 2016). G. zeae dominates in areas with warmer climates, especially where summer is warm (Magan et al. 2002; Hofgaard et al. 2016). This fungus is relatively rare in the spring wheat cultivars although it is increasingly contributing to FHB (Czaban et al. 2011; Lenc et al. 2015b). In our study, this pathogen was identified in $7.1 \%$ of all isolations. Both species were molecularly identified in PCR assays with speciesspecific primers that proved to be reliable for isolates from Poland by Baturo-Ciesniewska and Suchorzynska (2011). FHBi was affected independently by the precrop type, fungicidal treatment and cultivar type, but not sowing date. FHBi was also dependent on seasonal weather conditions during the three years of our study. FHBi ranged from $4.64 \%$ in 2013 to $13.84 \%$ in 2012 , with mean $8.48 \%$, which indicates a low level of disease. However, $25 \%$ of untreated wheat heads were 
Fig. 4 Correlations between total mycotoxin content and development duration at $\mathrm{BBCH}$ 69-89, incidence of Fusarium head blight and the proportions of G. zeae. F. culmorum and total Fusarium (FR) in wheat grains for different sowing dates

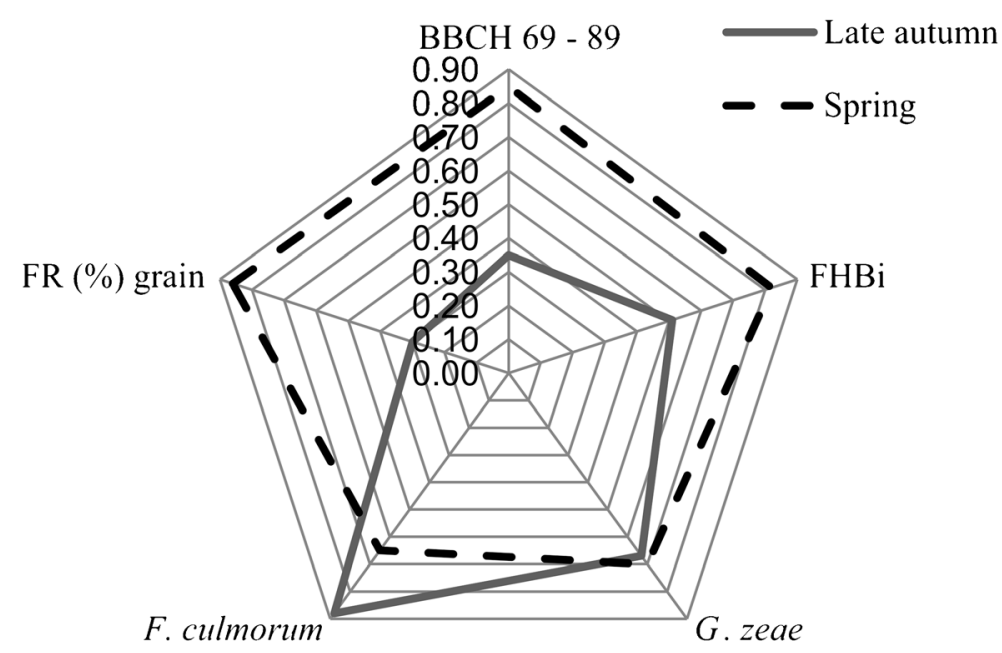

diseased in 2012, which was higher than in other study years. Such high incidences in 2012 can be explained by weather conditions favourable to FHB, including high rainfall $(114 \mathrm{~mm})$ and cool air temperatures $\left(15.5^{\circ} \mathrm{C}\right)$ during the critical phase, $\mathrm{BBCH} 65$. Rain intensity, duration, and frequency, and the size and velocity of falling drops, affect the splash dispersal of spores and the success of infection (Shin et al. 2014). However, intense rain may have a decreased effective dispersal effect by washing off newly-dispersed spores, which, therefore, did not contribute to increased Fusarium infections (Lenc et al. 2015b). Moreover, wind can increase the primary rain-dispersal distance in a downwind direction and decrease it upwind. Generally, winddispersal distances are longer than rain dispersal distances alone, and the pure splash dispersal is mostly local (Sache 2000).

The two wheat cultivars tested in our trials exhibited different FHB susceptibilities. Cv. Cytra had an FHBi twice that of cv. Monsun, which was expected after
Góral and Walentyn-Góral (2014)) findings. Thus, more $\mathrm{CFU} / \mathrm{g}$ on grain and a higher Fusarium ratio was an attribute of cv. Cytra grain. Consequently, higher mycotoxin levels were found in Cytra grain, especially for DON, ADON, HT-2 and ZEN. Moreover, the interaction of sowing season and pre-crop type was significant in term of Fusarium ratio (\%) in both wheat cultivars. Grain from more-susceptible Cytra had a higher Fusarium ratio when planted in spring or after wheat. This same pattern was not seen in the FHBi; because FHBi was assessed in samples collected directly from the field. Mycelia and conidia were probably not present on the grain surface, and consequently, they were not present in the liquid that was used as the inoculum on the YGC medium.

Our results showed that FHB was observed twice as frequently when wheat was grown in monoculture as compared to after sugar beets. Wheat sown after sugar beets had very low incidences of head diseases, as well as lower mycotoxin concentrations. Czaban et al. (2011) reported that intensive wheat cropping, high nitrogen

Table 6 Means and ranges of wheat characteristics correlated with total mycotoxin concentration in grain

\begin{tabular}{|c|c|c|c|c|c|c|}
\hline \multirow[t]{2}{*}{ Sowing date } & \multicolumn{6}{|l|}{ Characteristic } \\
\hline & $\begin{array}{l}\text { Total mycotoxins } \\
(\mu \mathrm{g} / \mathrm{kg})\end{array}$ & $\begin{array}{l}\text { BBCH 69-89 } \\
\text { (days) }\end{array}$ & FHBi $(\%)$ & $\begin{array}{l}\text { F. culmorum } \\
\text { isolations (\%) }\end{array}$ & G. zeae isolations (\%) & $\begin{array}{l}\text { Fusarium ratio } \\
\text { in grain }(\%)\end{array}$ \\
\hline \multirow[t]{2}{*}{ Late autumn } & $286.7^{\#}$ & 35 & 7.50 & 20.0 & 5.5 & 9.17 \\
\hline & $(36.5-1863)$ & $(31-42)$ & $(2.0-15.6)$ & $(10.0-30.0)$ & $(0.0-15.5)$ & $(1.00-28.0)$ \\
\hline \multirow[t]{2}{*}{ Spring } & 429.0 & 50 & 11.3 & 35.0 & 10.5 & 18.4 \\
\hline & $(38.0-2788)$ & $(44-54)$ & $(1.5-30.5)$ & $(5.0-55.5)$ & $(0.0-30.0)$ & $(2.00-43.0)$ \\
\hline
\end{tabular}

\# Mean data from the two cultivars $\mathrm{x}$ three pre-crop types $\mathrm{x}$ control vs. fungal treatments $\mathrm{x}$ three years $(n=36)$ 
inputs and incorporation of straw into the soil are more conducive to grain infection by FHB than IPM practices. Interactions of factors including host genetics, pathogen aggressiveness and toxin production capacity, and environmental conditions, particularly moisture, influence FHB development and the accumulation of mycotoxins in FHB-infested wheat (Gautam and DillMacky 2012). In seasons with rainfall levels, relative humidities and temperatures favouring FHB infestation, tillage and fertilization treatments have little to no impact on disease development. During seasons with moderate weather conditions, FHB may occur more frequently in no-till plots compared to conventional tillage plots, with subsequent increases in mycotoxin concentrations in grain (Lori et al. 2009). We tilled the plots used in this study using a uniform pattern for all precrop types and wheat cultivars. Pre-crop type impacted mould CFUs in grain as independent factor with higher amounts after wheat or corn, while Fusarium ratio (\%) after wheat. We found that DON and ZEN concentrations were higher in cv. Cytra and illustrated the interactions between cultivar and pre-crop and cultivar and sowing date in the same meaning as Fusarium isolations from moulds. In current study, wheat grown after corn exhibited the highest FHBi $(11.17 \%)$ and the highest FR (over 60\%). This is in agreement with the findings of Nitzsche et al. (2002), which described the risk of FHB in the Saxonia region for wheat following various precrop types, and concluded that corn as a pre-crop increased the risk of Fusarium infestation. A 10-year survey of randomly collected winter wheat samples within the Czech Republic also revealed the significant adverse effect of corn as the pre-crop on the accumulation of DON in wheat grain (Chrpová et al. 2015). Moreover, DON production by both of the DONproducing species $F$. culmorum and G. zeae was significantly higher in mixed infections with other species. The presence of $G$. avenacea ( $F$. avenaceum) among these species appeared to markedly promote the production of DON and NIV. Because G. avenacea was isolated in $17.2 \%$ of our samples, the same effect could be influencing the levels of mycotoxins produced by F. culmorum and G. zeae that we detected.

Sowing in late autumn results in earlier wheat development and ripening as compared with spring sowing (Wenda-Piesik et al. 2016). In current study, sowing season also impacted both of these disease characteristics, with higher intensity for spring sowings. We observed higher means and wider ranges of FHBi, higher
Fusarium ratios in grains, higher F. culmorum and $G$. zeae percentages in isolations, and increased duration of the phases between the end of flowering and the beginning of kernel abscission in spring sowings as compared to late autumn sowings. A longer developmental time for plants between BBCH 69-89 correlated with increased mycotoxin levels, as evidenced by the increasing FHBi and incidence levels of both G. zeae and F. culmorum on heads. Usually, wet weather results in the prolongation of this stage (from the end of flowering to the beginning of the fully ripe stage) in spring wheat infected by Fusarium spp., and favours the presence of the inocula. For late autumn-sown wheat, the total mycotoxin concentration was correlated with $\mathrm{FHBi}$, and G. zeae and F. culmorum incidences on heads, but not with the duration of BBCH 69-89 or FR in grain. Due to the advanced development and faster kernel maturation, wheat sown in late autumn exhibited reduced grain contamination levels and lower mycotoxin concentrations. Correlations and regressions among FHB symptoms caused by $F$. poae and $F$. avenaceum, fungal incidences, and toxin accumulation in wheat grains were studied on Swiss varieties under controlled inoculation conditions (Vogelsgang et al. 2007). The NIV content and F. poae incidence in grain was highly correlated, with an $r^{2}$ of 0.90 , while the correlation between disease symptoms was less strong $\left(r^{2}=0.56\right)$. Conversely, the correlation between the $F$. avenaceum incidence in grain and the MON content was rather low $\left(r^{2}=0.59\right)$, while with the correlation between disease symptoms and MON was greater $\left(r^{2}=0.77\right)$. In that study, the distribution of data had a high overall infection rate by $F$. avenaceum, starting at $70 \%$ infected grains, and its narrow range (70-90\%) explained the lower correlation with MON. Toxin concentrations in grains of plants that were artificially inoculated might not reflect the situation in commercial grain fields (Vogelsgang et al. 2007). Here, correlations exist in data collected under natural infection conditions. There were wide ranges for the features determining the mycotoxin concentrations, and their variations were related to the weather conditions and four agronomic factors. Their strongest correlations were: Fusarium ratio $(r=0.86), G$. zeae isolations $(r=0.70)$ and F. culmorum isolations $(r=0.65)$, which explained the toxin content in wheat grain from spring term sowing. The mycotoxin levels on wheat grain coming from late autumn sowing were correlated with FHBi $(r=0.51)$, G. zeae $(r=0.67)$ and F. culmorum isolations $(r=0.88)$. 
This significantly corroborates the theory of a relationship between FHB and mycotoxins in grain, which was described previously by Browne (2007) regarding the F. graminearum incidence and DON accumulation. However, the associations between disease symptoms, fungal incidence on grain and toxin content have not always been shown. Horoszkiewicz-Janka et al. (2012) found no correlation between different pre-crop types (rapeseed, corn and wheat) or tillage system (reduced vs. traditional) and DON or ZEN concentrations in wheat sown from 2009 to 2011 in Central Poland.

Fungicide applications to suppress FHB may be challenging, in part due to uneven flowering times within a single field, which may necessitate multiple costly applications. Due to the short application window (the period during, or shortly after, anthesis), unforeseen events such as unfavourable weather can prevent optimal application timing (Wegulo et al. 2015). Our analyses showed that fungicide treatment independently affected mould CFUs in grain as well as Fusarium isolations. The program including applications of the fungicides prothioconazole and spiroxamine at $\mathrm{T} 1$ and a mixture of fluoxastrobin and prothioconazole at T2 effectively reduced head disease and FR, as well as total moulds on grain and Fusarium incidence. However, when cv. Cytra was grown after corn, DON levels were relatively high. This indicated that cultivars susceptible to FHB should also be protected at the end of the flowering stage. Proper timing and application of fungicides is critical. If the window of opportunity is missed and infection occurs, later applications of fungicide will not prevent formation of DON (Yuen and Schoneweis 2007). Thus, a third treatment at stage T3 (BBCH 69) with, for example, a mixture of prothioconazole and tebuconazole (Paul et al. 2005), could be justified in wet June-July. Under moderate conditions, IPM practices such as crop rotations and proper cultivar choices should be employed to maintain low inoculum levels, with fungicides used only when necessary.

Co-occurrence of Fusarium mycotoxins, with the potential for synergistic or antagonistic toxin interactions, is a recurring problem in wheat production systems. European regulations set maximum tolerated limits and guidance values for several mycotoxins in food and feed, and designate methods for mycotoxin sampling and analysis (European Commission (EC) 2006a, 2006b, 2013).

In our investigation, the mean DON, NIV, ADON, ZEA, HT-2 and T-2 levels in grain did not exceed the maximum permissible values for unprocessed wheat. However, our study suggests that it is most important to monitor and mitigate FHB risk for susceptible cultivars, in years with high June rainfalls, when wheat sowing follows corn or wheat and when no fungicidal treatment is used.

Acknowledgements This research was supported by the Polish Ministry of Science and Education, Grant No: N N310 160838.

Open Access This article is distributed under the terms of the Creative Commons Attribution 4.0 International License (http:// creativecommons.org/licenses/by/4.0/), which permits unrestricted use, distribution, and reproduction in any medium, provided you give appropriate credit to the original author(s) and the source, provide a link to the Creative Commons license, and indicate if changes were made.

\section{References}

Abdullah, S. K., \& Atroshi, H. I. M. (2016). Mycobiota associated with grains of soft wheat (Triticum aestivm L.) cultivars grown in Duhok Province, Kurdistan region, Iraq. Journal of Agricultural Technology, 12(1), 91-104.

Aoki, T., O’Donnell, K., \& Geiser, D. M. (2014). Systematics of key phytopathogenic Fusarium species: Current status and future challenges. Journal of General Plant Pathology, 80, 189-201.

Arseniuk, E., Foremska, E., Góral, T., \& Chełkowski, J. (1999). Fusarium head blight reactions and accumulation of deoxynivalenol (DON) and some of its derivatives in kernels of wheat, triticale and rye. Journal of Phytopathology, 147, 577-590.

Bai, G., \& Shaner, G. (1994). Scab of wheat: Prospects for control. Plant Disease Reporter, 78, 760-766.

Basler, R. (2016). Diversity of Fusarium species isolated from UK forage maize and the population structure of $F$. graminearum from maize and wheat. Peer J, 4, e2143. doi:10.7717 /peerj.2143.

Baturo-Ciesniewska, A., \& Suchorzynska, M. (2011). Verification of the effectiveness of SCAR (sequence characterized amplified region) primers for the identification of polish strains of Fusarium culmorum and their potential ability to produce Btrichothecenes and zearalenone. International Journal of Food Microbiology, 148, 168-176.

Bennett, J. W., \& Klich, M. (2003). Mycotoxins. Clinical Microbiology Reviews, 16, 497-516.

Blandino, M., Haidukowski, M., Pascale, M., Plizzari, L., Scudellari, D., \& Reyneri, A. (2012). Integrated strategies for the control of fusarium head blight and deoxynivalenol contamination in winter wheat. Field Crops Research, 133, 139-149.

Bliss, C. I. (1938). The transformation of percentages for use in the analysis of variance. The Ohio Journal of Science, 38, 9-12.

Booth, C. (1971). The Genus Fusarium. England: Commonwealth Mycological Institute. 
Bottalico, A. (1998). Fusarium diseases of cereals: Species complex and related mycotoxin profiles, in Europe. Journal of Plant Pathology, 80, 85-103.

Bottalico, A., \& Perrone, G. (2002). Toxigenic Fusarium species and mycotoxins associated with head blight in small-grain cereals in Europe. European Journal of Plant Pathology, $108,611-624$.

Browne, R. A. (2007). Components of resistance to fusarium head blight (FHB) in wheat detected in a seed-germination assay with Microdochium majus and the relationships to FHB disease development and mycotoxin accumulation from Fusarium graminearum infection. Plant Pathology, 56, 6572.

Burgess, L. W. (1981). General ecology of the fusaria. In P. E. Nelson, T. A. Toussoun, \& R. J. Cook (Eds.), Fusarium: Diseases, biology, and taxonomy (pp. 225-235). Philadelphia: Pennsylvania State University Press.

Burlakoti, R. R., Mergoum, M., Kianian, S. F., \& Adhikari, T. B. (2010). Combining different resistance components enhances resistance to Fusarium head blight in spring wheat. Euphytica, 172, 197-205.

Champeil, A., Doré, T., \& Fourbet, J. T. (2004a). Fusarium head blight: Epidemiological origin of the effects of cultural practices on head blight attacks and the production of mycotoxins by Fusarium in wheat grains. Plant Science, 166, 13891415.

Champeil, A., Fourbet, J. F., Doré, T., \& Rossignol, L. (2004b). Influence of cropping system on Fusarium head blight and mycotoxins levels in winter wheat. Crop Protection, 23, 531537.

Chełkowski, J. (1998). Distribution of Fusarium species and their mycotoxins in cereal grains. In K. K. Sinha \& D. Bhatnagar (Eds.), Mycotoxins in agriculture and food safety (pp. 4564). New York: Marcel Dekker Inc..

Chełkowski, J., Visconti, A., Solfrizzo, M., \& Bottalico, A. (1984). Formation of mycotoxins by Fusarium species from cereals in Poland. Phytopathologia Mediterranea, 23, 43-46.

Chrpová, J., Šíp, V., Sumíková, T., Salava, J., Palicová, J., Štočková, L., Džuman, Z., \& Hajšlová, J. (2015). Occurrence of Fusarium species and mycotoxins in wheat grain collected in the Czech Republic. World Mycotoxin Journal, 9(2), 317-327.

Clark, B., Jorgensen, L. N., Antichi, D., Góral, T., Gouache, D., Hornok, L., Jahn, M., Lucas, P., Rolland B., \& Schepers, H. (2009). Strategies to control Fusarium ear blight and mycotoxin production in wheat. From Science to Field. Wheat Case Study — Guide Number 2. ENDURE [http://www. edndure-network.eu].

COBORU (2013). Results of Post Registered Cultivars Testing in Poland (pp. 45). Słupia Wielka.

Czaban, J., Wróblewska, B., Sułek, A., \& Podolska, G. (2011). Colonization of wheat grain by Fusarium in two crop management systems varying in intensity of production technology. Plant Breeding and Seed Science, 64, 3-13.

Desjardins, A. E. (2006). Fusarium mycotoxins: Chemistry, genetics, and biology. St. Paul: The American Phytopathological Society Press.

Dill-Macky, R., \& Jones, R. K. (2000). The effect of previous crop residues and tillage on Fusarium head blight of wheat. Plant Disease, 84, 71-76.
Doohan, F. M., Brennan, J., \& Cooke, B. M. (2003). Influence of climatic factors on Fusarium species pathogenic to cereals. European Journal of Plant Pathology, 109, 755-768.

Doyle, J. J., \& Doyle, L. (1990). Isolation of plant DNA from fresh tissue. Focus, 12, 13-15.

Duveiller, E. (2008). Examples of pests and diseases that can be affected by climate change. In In climate-related transboundary pests and diseases: Technical background document from the expert consultation held (pp. 25-27). Rome: FAO.

Edwards, S. G. (2004). Influence of agricultural practices on Fusarium infection of cereals and subsequent contamination of grain by trichothecene mycotoxins. Toxicology Letters, 153, 29-35.

Elvers, K. T., Leeming, K., Moore, C. P., \& Lappin-Scott, H. M. (1998). Bacterial-fungal biofilms in flowing water photoprocessing tanks. Journal of Applied Microbiology, 84, 607-618.

European Commission (EC). (2006a). Commission regulation (EC) no $1881 / 2006$ of the Commission of the European Communities setting maximum levels for certain contaminants in foodstuffs. Official Journal of the European Union L, 364, 1-35.

European Commission (EC). (2006b). Commission regulation (EC) no 401/2006 of the Commission of the European Communities laying down the methods of sampling and analysis for the official control of the levels of mycotoxins in foodstuffs. Official Journal of the European Union L, 70, $12-34$.

European Commission (EC). (2013). Commission recommendation (EC) no 165/2013 on the presence of T-2 and HT-2 toxin in cereals and cereal product. Official Journal of the European Union L, 91, 12-15.

European Commission (EC). (2015). Short term outlook for EU arable crops, dairy and meat markets in 2015 and 2016. Brussels: European Commission - Directorate General for Agriculture and Rural Development.

Food and Agriculture Organization FAO (2013). Cereal supply and demand brief. http://www. fao. org/worldfoodsituation/wfs-home/csdb/en/.

Gautam, P., \& Dill-Macky, R. (2012). Impact of moisture, host genetics and Fusarium graminearum isolates on Fusarium head blight development and trichothecene accumulation in spring wheat. Mycotoxin Research, 28, 45-58.

Golinski, P., Karczmarek, Z., Kiecana, I., Wisniewska, H., Kaptur, P., Kostecki, M., \& Chelkowski, J. (2002). Fusarium head blight of common polish winter wheat cultivars Comparison of effects of Fusarium avenaceum and Fusarium culmorum on yield components. Journal of Phytopathology, 150(3), 135-141.

Góral, T., \& Walentyn-Góral, D. (2014). Resistance of spring wheat cultivars and lines to fusarium head blight caused by Fusarium culmorum. Biuletyn Instytutu Hodowli $i$ Aklimatyzacji Roślin, 271, 2-16.

Goswami, R. S., \& Kistler, H. C. (2004). Heading for disaster: Fusarium graminearum on cereal crops. Molecular Plant Pathology, 5, 515-525.

Groves, F. D., Zhang, L., Chang, Y. S., Ross, P. F., Casper, H., Norred, W. P., You, W. C., \& Fraumeni, J. F. (1999). Fusarium mycotoxins in corn and corn products in a high- 
risk area for gastric cancer in Shandong Province, China. Journal of AOAC International, 82, 657-662.

Hinkelmann, K., \& Kempthorne, O. (2005). Design and analysis of experiments: Advanced experimental design. Hoboken: John Wiley \& Sons.

Hofgaard, I. S., Aamot, H. U., Torp, T., Jestoi, M., Lattanzio, V. M. T., Klemsdal, S. S., Waalwijk, C., Van der Lee, T., \& Brodal, G. (2016). Associations between Fusarium species and mycotoxins in oats and spring wheat from farmers' fields in Norway over a six-year period. World Mycotoxin Journal, 9(3), 365-378.

Horoszkiewicz-Janka, J., Jajor, E., \& Korbas, M. (2012). Prevalence of winter wheat diseases depending on selected agrotechnical factors. Progress in Plant Protection, 52, 9981004.

Jones, R. K., \& Mirocha, C. J. (1999). Quality parameters in small grains from Minnesota affected by Fusarium head blight. Plant Disease Journal, 83, 506-511.

Keller, M. D., Bergstrom, G. C., \& Shields, E. J. (2014). The aerobiology of Fusarium graminearum. Aerobiologia, 30, 123-136.

Korbas, M., \& Horoszkiewicz-Janka, J. (2007). Significance and possibilities of harmfulness reduction of fungal metabolites. Progress in Plant Protection, 47, 141-148.

Kwaśna, H., Chełkowski, J., \& Zajkowski, P. (1991). Grzyby (Mycota) (Vol. XXII). Warszawa-Kraków: Polish Academy of Sciences.

Lancashire, P. D., Bleiholder, H., Langelüddecke, P., Stauss, R., Van Den Boom, T., Weber, E., \& Witzenberger, A. (1991). An uniform decimal code for growth stages of crops and weeds. Annals of Applied Biology, 119, 561-601.

Lenc, L. (2015a). Fusarium head blight (FHB) and Fusarium populations in grain of winter wheat grown in different cultivation systems. Journal of Plant Protection Research, 55(1), 94-109.

Lenc, L., Czecholiński, G., Wyczling, D., Turów, T., \& Kaźmierczak, A. (2015b). Fusarium head blight (FHB) and Fusarium spp. on grain of spring wheat cultivars grown in Poland. Journal of Plant Protection Research, 55(3), 266277.

Leplat, J., Friberg, H., Abid, M., \& Steinberg, C. (2013). Survival of Fusarium graminearum, the causal agent of fusarium head blight. A review. Agronomy for Sustainable Development, 33, 97-111.

Leslie, J. F., Summerell, B. A., \& Bullock, S. (2006). The fusarium laboratory manual. Ames: Wiley-Blackwell Publishing.

Logrieco, A., \& Visconti, A. (Eds.). (2004). Overview of toxigenic fungi and mycotoxins in Europe. Dordrecht: Kluwer Academic Publishers.

Lori, G. A., Sisterna, M. N., Sarandón, S. J., Rizzo, I., \& Chidichimo, H. (2009). Fusarium head blight in wheat: Impact of tillage and other agronomic practices under natural infection. Crop Protection, 28, 495-502.

MacMullen, M., Jones, R., \& Gallenberg, D. (1997). Scab of wheat and barley: A re-emerging disease of devastating impact. Plant Disease, 81, 1340-1348.

Magan, N., Hope, R., Colleate, A., \& Baxter, E. S. (2002). Relationship between growth and mycotoxin production by Fusarium species, biocides and environment. European Journal of Plant Pathology, 108, 685-690.
Marasas, W. F. O., Nelson, P. E., \& Toussoun, T. A. (1984). Toxigenic fusarium species: Identity and mycotoxicology. University Park: Pennsylvania State University Press.

Nelson, P. E., Dignani, M. C., \& Anaissie, E. J. (1994). Taxonomy, biology, and clinical aspects of Fusarium species. Clinical Microbiology Reviews, 7, 479-504.

Nicholson, P., Simpson, D. R., Weston, G., Rezanoor, H. N., Lees, A. K., Parry, D., \& Joyce, D. (1998). Detection and quantification of Fusarium culmorum and Fusarium graminearum in cereals using PCR assays. Physiological and Molecular Plant Pathology, 53, 17-37.

Nicholson, P., Simpson, D. R., Wilson, A. H., Chandler, E., \& Thomsett, M. (2004). Detection and differentiation of trichothecene and enniatin-producing Fusarium species on smallgrain cereals. European Journal of Plant Pathology, 110, 503-514.

Nitzsche, O., Schmidt, W., \& Gebhart, C. (2002). Fusariumbefall vorbeugen. Neue Landwirtschaft, 5, 40-41.

OEPP/EPPO. (2012). EPPO standards PP 1/26(4), foliar and ear diseases on cereals. Bulletin OEPP/EPPO Bulletin, 42, 419425.

Park, R. F., Burdon, J. J., Guest, D. I., \& Ayliffe, M. J. (2009). Dynamics of crop-pathogen interactions: From gene to continental scale. In V. O. Sadras \& D. F. Calderini (Eds.), Applied crop physiology: At the boundaries with genetic improvement and agronomy (pp. 423-447). London: Elsevier.

Parry, D. W., Jenkinson, P., \& McLeod, L. (1995). Fusarium ear blight (scab) in small grain cereals - A review. Journal of Plant Pathology, 44, 207-238.

Paul, P., Hershman, D., Draper, M., \& Madden, L. (2005). Effects of fungicides on FHB and DON in wheat 2005 uniform fungicide trials. In S.M. Canty, T. Boring, J. Wardwell, L. Siler, \& R. W. Ward (Ed.), Proceedings of the National Fusarium Head Blight Forum, 2005 Dec.11-13 (pp. 225-229). Michigan State University, East Lansing.

Perkowski, J., Plattner, R. D., Goliński, P., Vesonder, R. F., \& Chełkowski, J. (1990). Natural occurrence of deoxynivalenol, 3-acetylodeoxynivalenol and zearalenone in polish wheat. Mycotoxin Research, 6, 7-12.

Perkowski, J., Chełkowski, J., Błażczak, P., Snijders, C. H. A., \& Wakuliński, W. (1991). A study of correlations between the amount of deoxynivalenol in grain of wheat and triticale and percentage of Fusarium damaged kernels. Mycotoxin Research, 7, 102-114.

Perkowski, J., Stachowiak, J., Kiecana, I., Goliński, P., \& Chełkowski, J. (1997). Natural occurrence of fusarium mycotoxins in polish cereals. Cereal Research Communications, 25, 379-380.

Sache, I. (2000). Short-distance dispersal of wheat rust spores by wind and rain. Agronomie, 20(7), 757-768.

Schaafsma, A. W., Tamburic-Ilinic, L., Miller, J. D., \& Hooker, D. C. (2001). Agronomic consideration for reducing deoxynivalenol in wheat grain. Canadian Journal of Plant Pathology, 23, 279-285.

Schmidt, M., Horstmann, S., De Colli, L., Danaher, M., Speer, K., Zannini, E., \& Arendt, E. K. (2016). Impact of fungal contamination of wheat on grain quality criteria. Journal of Cereal Science, 69, 95-103. 
Schollenberger, M., Müller, H. M., Rüfle, M., Suchy, S., Planck, S., \& Drochner, W. (2005). Survey of Fusarium toxins in foodstuffs of plant origin marketed in Germany. International Journal of Food Microbiology, 97, 317-326.

Shin, S., Kim, K. H., Kang, C. S., Cho, K. M., Park, C. S., Okagaki, R., \& Park, J. C. (2014). A simple method for the assessment of Fusarium head blight resistance in Korean wheat seedlings inoculated with Fusarium graminearum. Plant Pathology Journal, 30(1), 25-32.

Snijders, C.,H.,A. (2004). Resistance in wheat to Fusarium infection and trichothecene formation. Toxicology Letters, 153, $37-46$.

Steinmüller, R., Ziller, K., \& Frenzel, W. (2004). Ein Korn sieht Rot: Besatzanalyse oder Mykotoxin Nachweis. Mühle Mischfutter, 141, 377-382.

Timmermans, B. G. H., Osman, A. M., \& van der Burgt, G. J. H. M. (2009). Differences between spring wheat cultivars in tolerance to Fusarium seedling blight under organic field conditions. European Journal of Plant Pathology, 125, 377-386.

Tralamazza, S. M., Bemvenuti, R. H., Zorzete, P., de Souza Garcia, F., \& Corrêa, B. (2016). Fungal diversity and natural occurrence of deoxynivalenol and zearalenone in freshly harvested wheat grains from Brazil. Food Chemistry, 196, 445-450.

Turner, A. S., Lees, A. K., Rezanoor, H. N., \& Nicholson, P. (1998). Refinement of PCR-detection of Fusarium avenaceum and evidence from DNA marker studies for phylogenetic relatedness to Fusarium tricinctum. Journal of Plant Pathology, 47, 278-288.

Visconti, A., Chełkowski, J., \& Bottalico, A. (1986). Deoxynivalenol and 3-acetyldeoxynivalenol - mycotoxins associated with wheat head fusariosis in Poland. Mycotoxin Research, 2, 59-64.

Vogelsgang, S., Sulyok, M., Hecker, A., Jenny, E., Krska, R., Schumacher, R., \& Forrer, H.-R. (2007). Toxigenicity and pathogenicity of Fusarium poae and Fusarium avenaceum on wheat. European Journal of Plant Pathology, 122, 265276.

Wagacha, J. M., \& Muthomi, J. W. (2007). Fusarium culmorum: Infection process, mechanisms of mycotoxin production and their role in pathogenesis in wheat. Crop Protection, 26, 877885 .
Wakuliński, W., \& Chełkowski, J. (1993). Fusarium species causing scab of wheat, rye and triticale in Poland. Hodowla Roślin, Aklimatyzacja i Nasiennictwo, 37, 137-142.

Weber, R., Kita, W., Pusz, W., \& Kieloch, R. (2016). The variability of the occurrence of Fusarium culmorum in winter wheat grain in relation to climatic conditions and cultivation methods. Zemdirbyste-Agriculture, 103(1), 45-52.

Wegulo, S. N., Baenziger, P. S., Nopsa, J. H., Bockus, W. W., \& Hallen-Adams, H. (2015). Management of Fusarium head blight of wheat and barley. Crop Protection, 73, 100-107.

Wenda-Piesik, A., Holková, L., Solařová, E., \& Pokorný, R. (2016). Attributes of wheat cultivars for late autumn sowing in genes expression and field estimates. European Journal of Agronomy, 75, 42-49.

Willyerd, K. T., Li, C., Madden, L. V., Bradley, C. A., Bergstrom, G. C., Sweets, L. E., McMullen, M., Ransom, J. K., Grybauskas, A., Osborne, L., Wegulo, S. N., Hershman, D. E., Wise, K., Bockus, W. W., Groth, D., Dill-Macky, R., Milus, E., Esker, P. D., Waxman, K. D., Adee, E. A., Ebelhar, S. E., Young, B. G., \& Paul, P. A. (2012). Efficacy and stability of integrating fungicide and cultivar resistance to manage fusarium head blight and deoxynivalenol in wheat. Plant Disease, 96, 957-967.

Wiśniewska, H. (2005). Fuzarioza kłosów pszenicy. Postępy Nauk Rolniczych, 4, 15-30.

Witzenberger, A., Hack, H., \& van den Boom, T. (1989). Erläuterungen zum BBCH Dezimal-Code für die Entwicklungsstadien des Getreides - mit Abbildungen. Gesunde Pflanzen, 41, 384-388.

Xu, X.-M., Parry, D. W., Nicholson, P., Thomsett, M. A., Simpson, D., Edwards, S. G., Cook, B. M., Doohan, F. M., Brennan, J. M., Moretti, A., Tocco, G., Mule, G., Hornok, L., Giczey, G., \& Tatnell, J. (2005). Predominance and association of pathogenic fungi causing Fusarium ear blight in wheat in four European countries. European Journal of Plant Pathology, $112,143-154$.

Yuen, G. Y., \& Schoneweis, S. D. (2007). Strategies for managing Fusarium head blight and deoxynivalenol accumulation in wheat. International Journal of Food Microbiology, 119, 126-130.

Zhang, J., Luo, M., \& Shen, T. (2012). Identification and screening of resources resistant to Fusarium Head Blight (FHB) in winter wheat region of Northern China (pp. 6-7). Proceedings of the 4th International Symposium on Fusarium Head Blight. Nanjing. 